\title{
ASESMEN KEMAMPUAN MENGENAL HURUF ANAK USIA DINI MELALUI MEDIA BIGBOOK
}

\section{THE ASSESSMENT ABILITY TO KNOW THE LETTERS FOR EARLY CHILDREN THROUGH THE BIG BOOK MEDIA}

\author{
Risnita \\ Universitas Islam Negeri Sulthan Thaha Saifuddin Jambi, Indonesia \\ Email: nita_arpan@yahoo.com \\ Winda Oktaviana \\ Universitas Islam Negeri Sulthan Thaha Saifuddin Jambi, Indonesia \\ Email: winda_oktaviana@gmail.com
}

\begin{abstract}
Abstrak
Kemampuan mengenal huruf merupakan kemampuan yang penting dikembangkan pada anak untuk mempersiapkan anak memasuki jenjang pendidikan selanjutnya. Penelitian ini bertujuan untuk menilai atau asesmen kemampuan mengenal hururf anak usia dini melalui penggunaan media big book di Taman Kanak-kanak Mutiara Almadani Kota Sungai Penuh. Penelitian ini menggunakan pendekatan Penelitian Tindakan Kelas (classroom action research) kolaborasi. Populasi penelitian adalah anak Taman Kanak-kanak Mutiara Almadani Kota Sungai Penuh yang berjumlah 200 orang yang terbagi dalam 10 kelompok belajar dan teknik pengambilan sampelnya adalah cluster sampling, yaitu kelompok B3 yang berjumlah 20 orang anak. Teknik pengumpulan data adalah observasi, wawancara, dokumentasi, dan catatan lapangan. Teknik analisis data yang digunakan dalam penelitian ini yaitu analisis kuantitatif dengan persentase dan analisis kualitatif. Hasil penelitian menunjukkan bahwa ada peningkatan kemampuan mengenal huruf yaitu pada prasiklus sebesar $45 \%$ meningkat pada Siklus I menjadi $60,42 \%$, pada Siklus II meningkat sebesar $75 \%$ dan pada Siklus III menjadi $88,33 \%$ dengan kriteria berkembang sangat baik. Dengan demikian dapat disimpulkan bahwa media big book dapat mengembangkan kemampuan mengenal huruf anak di Taman Kanakkanak Taman Kanak-kanak Islam Mutiara Almadani Kota Sungai Penuh Kota Sungai Penuh.
\end{abstract}

Kata kunci: asesmen, kemampuan mengenal huruf, media big book, TK

\begin{abstract}
The ability to recognize letters is an important ability developed in children to prepare children to enter the next level of education. This study aims to develop the ability to recognize the letters in children using big book media in Mutiara Almadani Kindergarden. This research uses
\end{abstract}


Risnita \& Winda Oktaviana: Asesmen Kemampuan Mengenal Huruf Anak Usia Dini Melalui Media Bigbook

\begin{abstract}
classroom action research approach (collaborative classroom action research). The study population is children of Mutiara Almadani Kindergarten Sungai Penuh City which amounts to 200 people which is divided into 10 study groups and sampling technique is cluster sampling, that is B3 group which is 20 children. Data collection techniques are observation, interview, documentation, and field notes. Data analysis technique used in this research is quantitative analysis with percentage and qualitative analysis. The results showed that there was an increase in the ability to recognize letters that is in the initial condition of $45 \%$ increase in cycle I to $60,42 \%$, in cycle II increased by $75 \%$ and in cycle III to $88,33 \%$ with very developed criteria good. Thus it can be concluded that the media big book can develop the ability to recognize the letters of children in Mutiara Almadani Kindergarten Sungai Penuh City.
\end{abstract}

Keywords: assesment, the ability to recognize letters, media big book, kindergarten

\title{
A. Pendahuluan
}

Anak-anak adalah perhiasan kehidupan di dunia. Anak adalah amanah yang dititipkan oleh Allah SWT. kepada orang tua. Imam Al-Ghazali dalam Suwaid mengatakan bahwa anak adalah amanat di tangan kedua orang tuanya, hatinya yang suci adalah mutiara yang masih mentah, belum dipahat maupun dibentuk. Mutiara ini dapat dipahat dalam bentuk apapun, mudah condong kepada segala sesuatu. Apabila dibiasakan dan diajari dengan kebaikan maka dia akan tumbuh dalam kebaikan. Dampaknya kedua orang tuanya akan hidup bahagia di dunia dan akhirat.

Wiyani \& Barnawi menyatakan bahwa Anak usia dini adalah anak yang baru dilahirkan sampai dengan usia 6 tahun. ${ }^{1}$ Menurut Aisyah, dkk, anak usia dini sering juga disebut dengan golden age atau usia emas karena rentang usia ini anak mengalami pertumbuhan dan perkembangan yang sangat pesat dalam berbagai aspek. Pada masa ini semua potensi yang dimiliki oleh anak berkembang dengan sangat cepat. ${ }^{2}$

Santrock menjelaskan early childhood (sometimes the "preschool years") extends from the end of infancy to about 5 or 6 years. During this period, children become more self-sufficient, develop school readiness skill (such as learning to follow

\footnotetext{
${ }^{1}$ Novan Ardy Wiyani \& Barnawi, Format PAUD (Yogyakarta:Ar-Ruzz Media, 2012), 32.

${ }^{2}$ Siti Aisyah, et.al., Perkembangan dan Konsep Dasar Pengembangan Anak Usia Dini (Jakarta: Universitas Terbuka, 2010), 17.
} 
instructions and identify letters), and spend many hours with peers. First grade typically marks the end of early childhood. ${ }^{3}$

Masa kanak-kanak merupakan salah satu masa terpenting dalam rentang kehidupan manusia. Sebab, ia menjadi pijakan fase-fase selanjutnya dalam proses pendidikan dan pembinaan pribadi. Menurut Mutiah, kehidupan pada masa anak merupakan suatu periode yang disebut dengan periode kritis ataupun periode sensitif dimana kualitas perangsangan harus diatur sebaik-baiknya, tentunya memerlukan intervensi baik dari guru maupun orang tua. ${ }^{4} \mathrm{Hal}$ ini diperkuat dengan penelitian yang dilakukan oleh Blooms dalam Mulyasa bahwa separuh potensi manusia sudah terbentuk ketika berada dalam kandungan sampai usia 4 tahun, dan 30\% terbentuk pada usia 4-8 tahun. Dengan demikian, $80 \%$ potensi manusia tersebut terbentuk pada masa usia dini. ${ }^{5}$

Undang-undang No. 20 Tahun 2003 tentang Sistem Pendidikan Nasional pasal 1 ayat 14 menyebutkan bahwa Pendidikan Anak Usia Dini (PAUD) adalah suatu upaya pembinaan yang ditujukan kepada anak sejak lahir sampai dengan usia enam tahun yang dilakukan melalui pemberian rangsangan pendidikan untuk membantu pertumbuhan dan perkembangan jasmani dan rohani agar anak memiliki kesiapan dalam memasuki pendidikan lebih lanjut. ${ }^{6}$

Berdasarkan Tingkat Pencapaian Perkembangan Anak Usia Dini (STPPA) yang berisi kaidah pertumbuhan dan perkembangan anak sejak lahir sampai dengan usia enam tahun yaitu meliputi aspek perkembangan nilai agama dan moral, fisik motorik, bahasa, sosial emosional, serta seni. Aspek-aspek yang dimiliki tersebut perlu mendapat rangsangan dan perhatian yang baik.

Salah satu lingkup aspek perkembangan yang harus dikembangkan di taman kanak-kanak adalah kemampuan bahasa. Kemampuan bahasa pada dasarnya mencakup kegiatan membaca, menyimak, berbicara, dan menulis. Kemampuan membaca merupakan bagian dari aspek perkembangan bahasa. Kemampuan dalam membaca sangatlah penting terutama dalam masa pertumbuhan kecerdasan, karena ilmu pengetahuan sebagian besar diperoleh melalui membaca. Patmonodewo menyatakan

\footnotetext{
${ }^{3}$ Jhon W. Santrock, Education Psycology (Newyork: McGraw-Hill, 2006), 35.

${ }^{4}$ Diana Mutiah, Psikologi Bermain Anak Usia Dini (Jakarta: Kencana Prenada Media Group, 2012), 3

${ }^{5}$ E. Mulyasa, Manajemen PAUD (Bandung: PT. Remaja Rosdakarya, 2012), 44

${ }^{6}$ Departemen Pendidikan Nasional, Undang-Undang Sistem Pendidikan Nasional (Jakarta: Departemen Pendidikan Nasional 2003), 3.
} 
Risnita \& Winda Oktaviana: Asesmen Kemampuan Mengenal Huruf Anak Usia Dini Melalui Media Bigbook

bahwa TK merupakan tempat bermain sambil belajar. Di TK tidak diberikan pelajaran membaca tapi yang diberikan adalah usaha atau kegiatan persiapan membaca permulaan. Untuk mempersiapkan kemampuan anak tersebut, anak terlebih dahulu dikenalkan dengan huruf. ${ }^{7}$

Menurut Qadratillah, dkk dalam Kamus Bahasa Indonesia untuk Pelajar, "huruf" didefinisikan sebagai tanda aksara dalam tata tulis yang merupakan anggota abjad yang melambangkan bunyi bahasa. ${ }^{8}$ Berdasarkan pengertian tersebut, dapat dikatakan huruf adalah lambang dari bunyi. Sedangkan kemampuan adalah kecakapan yang diperoleh melalui belajar dan berlatih.

Musfiroh menyatakan bahwa kemampuan mengenal huruf adalah anak mampu mengidentifikasi huruf-huruf dan membuat sendiri huruf-huruf tersebut. ${ }^{9}$ Dalam hal ini anak mampu mengamati hubungan antara suara dan huruf. Stimulasi pengenalan huruf adalah merangsang anak untuk mengenali, memahami dan menggunakan simbol tertulis untuk berkomunikasi. Sedangkan Seefeld dan Wasik, saat mempelajari huruf-huruf, anak-anak secara khas mengikuti urutan perkembangan yaitu mengenal huruf, bunyi huruf dan belajar asosiasi bunyi-huruf. ${ }^{10}$ Dari pendapat di atas adapun yang dimaksud kemampuan mengenal huruf dalam penelitian ini adalah anak mampu mengenal simbol huruf, mengenal bunyi huruf dan memahami asosiasi bunyi dan simbol huruf.

Pada akhir taman kanak-kanak anak harus bisa mengenal dan menyebutkan semua huruf, belajar banyak kesepadanan bunyi satu huruf ke huruf yang lain. Menurut Dyer, pada akhir tahun taman kanak-kanak anak secara khusus dapat mengetahui bunyi dari semua abjad, mengenali dan menamakan huruf. ${ }^{11}$

Pendapat ini sejalan dengan Peraturan Menteri Pendidikan dan Kebudayaan Republik Indonesia Nomor 137 Tahun 2014 (Kementerian Pendidikan dan Kebudayaan, tentang Standar Nasional Pendidikan Anak Usia Dini bahwa tingkat capaian perkembangan anak usia 5 sampai 6 tahun pada lingkup perkembangan bahasa yaitu keaksaraan terutama yang berkaitan dengan kemampuan mengenal huruf yaitu: 1) Anak

\footnotetext{
${ }^{7}$ Soemiarti Patmonodewo, Pendidikan Anak Prasekolah (Jakarta: Rieneka Cipta, 2008), 29

${ }^{8}$ Meity Taqdir Qadratillah, et.al., Kamus Bahasa Indonesia untuk Pelajar, (Jakarta: Badan Pengembangan dan Pembinaan Bahasa, Kementerian Pendidikan dan kebudayaan, 2011), 166.

${ }^{9}$ Tadkiroatun Musfiroh, Bermain Sambil Belajar dan Mengasah Kecerdasan (Jakarta: Departemen Pembinaan Tenaga Kependidikan dan Ketenagaan Perguruan Tinggi. 2009), 10.

${ }^{10}$ Carold Seefeldt dan Barbara A. Wasik, Pendidikan Anak Usia Dini, Terjemahan Piur Nasar (Jakarta: PT. Indeks. 2008), 333.

${ }^{11}$ Laura Dyer, Meningkatkan Kemampuan Bicara Anak (Jakarta: Bhuana Ilmu Populer, 2009), 210.
} 
mampu menyebutkan simbol-simbol huruf yang dikenal, 2) Anak mampu mengenal suara huruf awal dari nama benda-benda yang ada disekitarnya, 3) Anak mampu menyebutkan kelompok gambar yang memiliki bunyi/ huruf awal yang sama, 4) Anak mampu memahami hubungan antara bunyi dan bentuk huruf. Dengan demikian, dapat dinyatakan bahwa anak usia 5-6 tahun diharapkan mampu untuk mengenal huruf. ${ }^{12}$

Berdasarkan grand tour yang dilakukan peneliti di lapangan ditemukan pada Taman Kanak-kanak Mutiara Almadani Kota Sungai Penuh, bahwa kemampuan anak dalam mengenal huruf belum berkembang secara optimal. Anak masih kesulitan dalam mengenal simbol huruf, bunyi huruf, serta asosiasi bunyi dan simbol huruf. Permasalahan-permasalahan yang dikemukakan di atas menunjukkan rendahnya kemampuan anak dalam mengenal huruf. Selain dari permasalahan tersebut, ditemukan pula media yang digunakan guru dalam mengenalkan huruf kurang menarik bagi anak serta kurang bervariasi. Guru hanya menggunakan papan tulis.

Kegiatan mengenalkan huruf dilakukan dengan cara guru menulis di papan tulis huruf-huruf satu persatu misalnya: a, b, c, d, e dan seterusnya. Pengenalan huruf-huruf yang dilakukan guru yaitu dengan cara menyebutkan (melafalkan) huruf-huruf yang dimaksud. Kemudian guru menyebutkan lafal huruf itu secara benar. Kegiatan ini membuat aktivitas pengenalan huruf menjadi kurang menyenangkan karena bersifat hapalan. Selain itu, kelemahan lainnya adalah pengenalan huruf dengan menggunakan papan tulis tidak disertai dengan gambar yang menarik dan berwarna warni sehingga membuat anak menjadi kurang tertarik. Oleh sebab itu, penggunaan media pembelajaran kurang bervariasi dan belum maksimal, belum dapat mempengaruhi ketertarikan anak dalam mengikuti proses pembelajaran.

Permasalahan-permasalahan yang dikemukakan di atas perlu dilakukan pemecahannya untuk mendapatkan jawabannya agar kemampuan mengenal huruf dapat dikembangkan dengan cara yang tepat dan menyenangkan. Oleh karena itu, salah satu solusi dalam mengatasi permasalahan di atas, peneliti menerapkan penggunaan media big book dalam mengembangkan kemampuan mengenal huruf pada anak.

Menurut Sholehuddin, dkk media big book merupakan salah satu media yang tepat digunakan untuk pengenalan huruf di taman kanak-kanak. Media big book (buku

\footnotetext{
${ }^{12}$ Kementerian Pendidikan dan Kebudayaan, Peraturan Menteri Pendidikan dan Kebudayaan Republik Indonesia Nomor 137 Tahun 2014 tentang Standar Pendidikan Anak Usia Dini (Jakarta: Kementerian Pendidikan dan Kebudayaan. 2015), 26.
} 
Risnita \& Winda Oktaviana: Asesmen Kemampuan Mengenal Huruf Anak Usia Dini Melalui Media Bigbook

besar) berukuran kurang lebih $40 \mathrm{~cm}$ x $60 \mathrm{~cm} .{ }^{13}$ Sedangkan menurut Madyawati, big book adalah buku bergambar yang dipilih untuk dibesarkan memiliki karakteristik khusus, yaitu adanya pembesaran baik teks maupun gambarnya. Hal ini sengaja dilakukan supaya terjadi kegiatan membaca bersama (shared reading) antara guru dan murid dan orang tua bersama anak. ${ }^{14}$

Fisher mengungkapkan bahwa media big book dapat digunakan dalam strategi pengenalan huruf dan bunyi. ${ }^{15}$ Selanjutnya Kasihani K. Suyanto menyatakan media big book merupakan media yang disenangi anak-anak dan dapat dibuat sendiri oleh guru. ${ }^{16}$ Dengan demikian, untuk mengembangkan kemampuan mengenal huruf pada anak dapat dilakukan dengan menggunakan media big book.

\section{B. Kajian Teori}

\section{Kemampuan Mengenal Huruf pada Anak}

Kemampuan mengenal huruf merupakan kemampuan yang penting untuk dikembangkan pada anak-anak untuk mempersiapkan anak memasuki jenjang pendidikan selanjutnya. Siskandar mengatakan bahwa kemampuan adalah pengetahuan, keterampilan, nilai-nilai dan sikap yang perlu dimiliki dan dilatihkan kepada peserta didik untuk membiasakan mereka berfikir dan bertindak. Kemampuan ini perlu dimahirkan dan dikembangkan sesuai dengan kebutuhan. Kemampuan merupakan suatu kesanggupan atau kapasitas yang dimiliki seseorang dalam melakukan tindakan yang dihasilkan dari pembawaan sejak lahir namun kemampuan ini akan berkembang jika diberikan latihan-latihan sehingga mampu melakukan sesuatu dengan baik. ${ }^{17}$

Berdasarkan pendapat tersebut dipahami bahwa kemampuan merupakan daya atau kesanggupan untuk melakukan suatu tindakan sebagai hasil dari pembawaan dan latihan untuk membiasakan anak berfikir dan bertindak. Salah satu kemampuan yang perlu dikuasai di taman kanak-kanak adalah kemampuan mengenal huruf.

Menurut Musfiroh, kemampuan mengenal huruf adalah anak mampu mengidentifikasi huruf-huruf dan membuat sendiri huruf-huruf tersebut. Dalam hal ini

\footnotetext{
${ }^{13}$ M. Sholehuddin, dkk, Pembaharuan Pendidikan TK (Jakarta: Universitas Terbuka, 2010), 7.3.

${ }^{14}$ Lilis Madyawati, Strategi Pengembangan Bahasa pada Anak (Jakarta: Prenadamedia Group, 2016), 174.

${ }^{15} \mathrm{M}$. Sholehuddin, dkk, Pembaharuan Pendidikan TK, 7.45

${ }^{16}$ Kasihani K.E. Suyanto, English for Young Learners (Jakarta: Bumi Aksara, 2008), 14.

${ }^{17}$ Choirun Nisak Aulina, "Pengaruh Permainan dan Penguasaan Kosakata terhadap Kemampuan Membaca Permulaan Anak Usia 5-6 Tahun,” Jurnal Pendidikan Anak Usia Dini, Vol. 6, No. 2 (2012), 36
} 
anak mampu mengamati hubungan antara suara dan huruf. Stimulasi pengenalan huruf adalah merangsang anak untuk mengenali, memahami dan menggunakan simbol tertulis untuk berkomunikasi. ${ }^{18}$

Berdasarkan pendapat di atas, maka dapat dirumuskan bahwa kemampuan mengenal huruf adalah kesanggupan anak untuk mampu mengidentifikasi huruf yaitu anak mampu mengenal simbol huruf, mengenal bunyi huruf dan memahami asosiasi bunyi dan bentuk huruf. Dalam hal ini huruf yang dimaksudkan adalah mengenal huruf abjad.

Menurut Seefeld dan Wasik, belajar huruf adalah tonggak kurikulum taman kanak-kanak lewat penyingkapan berulang dan bermakna kepada peristiwa-peristiwa baca tulis, sehingga anak tahu akan huruf-huruf dan mengerti bahwa huruf-huruf membentuk sebuah kata. ${ }^{19}$ Goodman dan Smith sebagaimana dikutip oleh Yulsyofriend, menyimpulkan bahwa pengenalan anak tentang fungsi cetakan (huruf) merupakan langkah pertama dalam proses membaca. Tahap kedua anak lebih memperhatikan bentuk cetakan secara lebih rinci. Selanjutnya pada tahap ketiga anak menyadari adanya konvensi bahwa tulisan dibaca dari kiri ke kanan, tanda baca digunakan dengan suatu maksud, jarak dipakai untuk memisahkan kata atau huruf dan seterusnya. ${ }^{20}$

Montessori memberikan pengertian bahwa suatu unsur (misalnya unsur huruf) akan mempunyai makna jika unsur tersebut bertalian atau berhubungan (berasosiasi) dengan unsur lain sehingga membentuk suatu arti Unsur huruf tidak akan memiliki makna apa-apa jika tidak bergabung (sintesa) dengan unsur (huruf) lain sehingga membentuk suatu kata atau kalimat bermakna. Atas dasar itu, Montessori dalam pengenalan huruf mempergunakan bantuan gambar. Setiap memperkenalkan huruf, misalnya huruf a disertai dengan gambar ayam, angsa (jenis binatang) atau anggur, apel. $^{21}$

Pendapat tersebut sejalan dengan penelitian yang dilakukan oleh Cattel dalam Robert, et.al., yang menemukan bahwa kemampuan partisipan untuk mengenali dan melaporkan huruf-huruf tidaklah terkait dengan jumlah huruf yang ditampilkan, melainkan terkait dengan pemaknaan urutan huruf-huruf tersebut. Seorang partisipan

\footnotetext{
${ }^{18}$ Tadkiroatun Musfiroh, Bermain Sambil Belajar..., 10

${ }^{19}$ Carold Seefeldt dan Barbara A. Wasik, Pendidikan..., 375

${ }^{20}$ Yulsyofriend, Permainan Membaca dan Menulis Anak Usia Dini (Padang: Sukabina, 2009), 67

${ }^{21}$ Ibid., 88
} 
yang dipaparkan huruf-huruf yang tidak saling berhubungan (tidak bermakna) selama 10 milidetik mampu menyebutkan 3 sampai 4 huruf, namun jika huruf-huruf tersebut membentuk sebuah kata (yang masing-masing terdiri dari tiga atau empat huruf) dan jika kata-kata tersebut memiliki hubungan sintaksis, partisipan yang bersangkutan mampu membaca empat kata sekaligus. ${ }^{22}$

Pengenalan huruf melalui kata-kata bermakna dapat mengembangkan kemampuan anak dalam mengenal huruf dibandingkan dengan mengenalkan huruf secara terpisah atau tidak saling berhubungan atau susunan huruf-huruf yang tidak memiliki arti. Oleh karena itu dalam mengenalkan huruf pada anak, dapat dilakukan melalui kata-kata bermakna.

Berdasarkan paparan teori di atas maka dapat dipahami bahwa kemampuan mengenal huruf adalah kesanggupan anak untuk mampu mengidentifikasi huruf-huruf dan membuat sendiri huruf-huruf tersebut. Dalam hal ini anak mampu mengamati hubungan antara suara dan huruf. Kemampuan mengenal huruf di taman kanak-kanak merupakan langkah untuk mempersiapkan anak mengenal bacaan. Pengenalan huruf sejak usia taman kanak-kanak yang penting diajarkan melalui kegiatan pengajaran tanpa membebani anak serta melalui kegiatan belajar yang menyenangkan. Oleh sebab itu mengenal huruf penting bagi anak taman kanak-kanak dan perlu diajarkan dengan kegiatan pembelajaran yang menyenangkan disertai media yang menarik.

\section{Media Big book}

Media berasal dari bahasa Latin dan merupakan bentuk jamak dari kata medium yang secara harfiah mempunyai arti antara, perantara atau pengantar. ${ }^{23}$ Pendapat ini sejalan dengan Kustandi yang menyatakan bahwa media adalah perantara atau pengantar pesan dari pengirim ke penerima pesan. ${ }^{24}$ Penggunaan media dalam kegiatan pendidikan anak usia dini berfungsi untuk mencapai tujuan pembelajaran, di mana dengan penggunaan media dapat memperjelas penyajian pesan dan informasi sehingga dapat memperlancar serta meningkatkan proses serta hasil belajar. Penggunaan media sangat dianjurkan untuk mempertinggi kualitas pembelajaran.Tanpa media maka proses

\footnotetext{
${ }^{22}$ Robert L. Solso, et al., Psikologi Kognitif, (Penterjemah: Mikael Rahardanto dan Kristianto Batuaji) (Jakarta: Erlangga, 2008), 339

${ }^{23}$ Nurbiana Dhieni, et.al., Metode Pengembangan Bahasa. Jakarta: Universitas Terbuka, 2008, 10.3

${ }^{24}$ Cecep Kustandi, Media Pembelajaran Manual dan Digital (Bogor: Ghalia Indonesia, 2011), 7
} 
pembelajaran tidak akan efektif. Salah satu media yang digunakan dalam pembelajaran di TK adalah media big book.

Media big book termasuk ke dalam jenis media visual yang dapat dilihat. Melalui media big book anak dapat melihat secara langsung gambar serta tulisan yang ada di dalam big book. Media big book adalah buku bergambar yang dipilih untuk dibesarkan memiliki karakteristik khusus, yaitu adanya pembesaran baik teks maupun gambarnya.

Big book is a book which has a big size as well as font. Due to the size which different from ordinary books. Big book can be seen easily from all part of the class. Besides, it has also colourful series picture inside to help students became more understand about the content of the story or even stimulate students situation. ${ }^{25}$ Big book adalah buku yang memiliki ukuran dan tulisan yang besar. Karena ukuran yang berbeda dari buku-buku biasa. Buku besar dapat dilihat dengan mudah dari semua bagian dari kelas. Selain itu, ia memiliki gambar yang berwarna-warni untuk membantu siswa menjadi lebih mengerti tentang isi cerita atau bahkan menstimulasi siswa.

Big book adalah istilah buku besar yang menggambarkan buku dengan format besar dengan teks yang dicetak besar dan ilustrasi yang sangat terlihat untuk peserta didik di seluruh ruang kelas dalam kelompok kecil, diikuti dengan meminta siswa untuk berpartisipasi langsung dengan mengulang kembali bacaan. ${ }^{26}$ Sedangkan menurut Suyanto, big book juga merupakan media yang disenangi anak-anak dan dapat dibuat sendiri oleh guru. Di dalamnya ditulis wacana sederhana, singkat dengan huruf yang besar dan diberi atau ditempeli gambar-gambar berwarna. ${ }^{27}$

Berdasarkan uraian teori, dapat dipahami bahwa media big book dalam penelitian ini adalah media visual berupa buku bergambar yang berukuran besar baik teks maupun gambarnya, dan memiliki kualitas khusus yang disenangi oleh anak-anak seperti dapat melibatkan ketertarikan anak dengan cepat karena gambar yang dimilikinya, gambar dan teks yang besar, dan memuat kosa kata yang direncanakan oleh guru.

\footnotetext{
${ }^{25}$ Lilis Madyawati, Strategi..., 174

${ }^{26}$ Usan Colville dan Barbara O'Connor Hall, "Using Big books: A Standards-Based Instructional Approach For Foreign Language Teacher Candidates in a Prek-12 Program," Foreign Language Annals, Vol. 39, No. 3 (2006), 488.

${ }^{27}$ Kasihani K.E. Suyanto, English..., 104
} 
Risnita \& Winda Oktaviana: Asesmen Kemampuan Mengenal Huruf Anak Usia Dini Melalui Media Bigbook

Strickland dan Morrow berpendapat bahwa big book merupakan buku besar yang berisi bacaan yang dicetak dalam ukuran besar yang digunakan untuk anak-anak. ${ }^{28}$ Selanjutnya Lynch dalam Madyawati, menyatakan big book creates secure and relaxed atmosphere in the classroom and attracts students attention in teaching and learning process. Big book menciptakan suasana aman dan santai di dalam kelas dan menarik perhatian siswa dalam proses belajar mengajar. ${ }^{29}$

Media big book juga memiliki banyak keutamaan. Beberapa keutamaan media big book yang dikemukakan oleh para ahli antara lain: 1) Holdaway menjelaskan media big book memberikan kesempatan kepada anak untuk terlibat dalam situasi nyata dengan cara yang tidak menakutkan. 2) Goodman menjelaskan media big book memungkinkan semua anak bisa melihat tulisan yang sama manakala guru membaca tulisan tersebut. 3) Hancock dan Hill menjelaskan bahwa penggunaan media big book memungkinkan anak-anak secara bersama-sama dan dengan bekerjasama memberi makna kepada tulisan didalamnya. 4) Sedangkan menurut Graham media big book memberikan kesempatan kepada anak untuk mengenali tulisan (huruf) dengan bantuan guru dan teman-teman lainnya. Media big book membuat guru dan anak berbagi keceriaan dan kegiatan secara bersama. ${ }^{30}$

Berdasarkan pendapat beberapa ahli dapat dirumuskan bahwa keutamaan media big book adalah memiliki gambar dan huruf yang berukuran besar yang dapat memberikan kesempatan kepada semua anak untuk terlibat dalam situasi yang nyata, anak dapat melihat dan mengenali secara bersama-sama tulisan yang ada pada media big book sehingga guru dan anak dapat berbagi keceriaan dan kegiatan bersama tanpa rasa takut salah. Oleh karena itu media big book sangat cocok digunakan sebagai media dalam pembelajaran dengan optimal.

\section{Kaitan Penggunaan Media Big book dengan Kemampuan Mengenal Huruf}

Media big book memiliki tulisan dan gambar yang dibesarkan yang akan mempermudah anak dalam melihat tulisan dan gambar yang sama. Fisher mengatakan bahwa dengan menggunakan media big book kita dapat menggunakan strategi pengenalan huruf dan bunyi kemudian menanyakan kepada anak-anak pengetahuan

\footnotetext{
${ }^{28}$ Magdalena M. Ocbian, et.al., "Big books' as Mother Tongue-Based Instructional Materials in Bicol for Grade One Pupils," Asia Pasific Journal of Multidisciplinary Research, Vol. 3, No. 4 (2015), 53

${ }^{29}$ Lilis Madyawati, Strategi..., 174

${ }^{30}$ M. Sholehuddin, dkk, Pembaharuan Pendidikan TK, 7.41
} 
mereka tentang huruf dan bunyi yang mereka lihat pada bacaan dalam big book. Melalui media big book yang berukuran besar baik gambar dan teksnya serta berwarna warni dan memungkinkan kegiatan shared reading antara guru dan murid melalui kata bermakna sehingga tercipta kegiatan pembelajaran yang menyenangkan, tidak membebani anak dalam mengenal huruf. Oleh karena itu media big book merupakan media yang tepat digunakan dalam mengembangkan kemampuan mengenal huruf di taman kanak-kanak.

\section{Metode Penelitian}

Pendekatan penelitian yang digunakan dalam penelitian ini adalah penelitian tindakan kelas (classroom action research) kolaborasi dengan prosedur yang dikemukakan oleh Kemmis dan Taggart. Menurut Aqib, penelitian tindakan kelas kolaborasi maksudnya adalah peneliti dengan guru kelas bekerjasama dalam melaksanakan proses pembelajaran. ${ }^{31}$ Sedangkan menurut Yufiarti dan Chandrawari, penelitian tindakan kelas merupakan pencermatan terhadap kegiatan yang sengaja dimunculkan dan terjadi di kelas. PTK merupakan salah satu cara yang strategis bagi guru untuk memperbaiki layanan kependidikan yang harus diselenggarakan dalam konteks pembelajaran di kelas dan peningkatan kualitas program sekolah secara keseluruhan. $^{32}$

Populasi dalam penelitian ini adalah anak-anak di Taman Kanak-kanak Mutiara Almadani kelompok B3 usia 5-6 tahun dengan jumlah anak 20 orang. Jenis data yang digunakan dalam proses penelitian ini terbagi menjadi dua jenis data, yaitu data primer dan data sekunder. Adapun sumber data dalam penelitian ini adalah anak Taman Kanakkanak Mutiara Almadani Kota Sungai Penuh yang menjadi sampel penelitian serta dokumen-dokumen, catatan, gambar, dan lain-lain, seperti struktur organisasi TK Mutiara Al-Madani Kota Sungai Penuh, data tentang sekolah, kepala sekolah, data guru dan karyawan serta muridnya.

Teknik pengumpulan data yang digunakan oleh peneliti untuk mengumpulkan data yaitu melalui observasi, wawancara, dokumentasi dan catatan lapangan.

\footnotetext{
${ }^{31}$ Zainal Aqib, Penelitian Tindakan Kelas Bagi Pengembangan Profesi Guru (Bandung: Yrahma Widya, 2006), 27.

${ }^{32}$ Yufiarti dan Titi Chandrawari, Profesionalitas Guru PAUD (Jakarta: Universitas Terbuka, 2010), 4.29
} 
Risnita \& Winda Oktaviana: Asesmen Kemampuan Mengenal Huruf Anak Usia Dini Melalui Media Bigbook

Adapun kisi-kisi instrumen kemampuan mengenal huruf anak usia 5-6 tahun adalah sebagai berikut:

Tabel 1. Kisi-kisi Instrumen Kemampuan Mengenal Huruf Anak

\begin{tabular}{|c|c|c|c|c|c|c|}
\hline \multirow{3}{*}{ Variabel } & \multirow{3}{*}{ Indikator } & \multirow{3}{*}{ Item } & \multicolumn{4}{|c|}{ KriteriaPenilaian } \\
\hline & & & BB & MB & BSH & BSB \\
\hline & & & 1 & 2 & 3 & 4 \\
\hline \multirow[t]{8}{*}{$\begin{array}{l}\text { Kemampuan } \\
\text { mengenal } \\
\text { huruf }\end{array}$} & $\begin{array}{l}\text { Mengenal } \\
\text { symbol huruf }\end{array}$ & $\begin{array}{l}\text { Menyebutkan simbol- } \\
\text { simbol huruf yang } \\
\text { dikenal pada media } \\
\text { big book }\end{array}$ & & & & \\
\hline & & $\begin{array}{l}\text { Menyebutkan symbol } \\
\text { huruf vocal pada kata } \\
\text { di media big book }\end{array}$ & & & & \\
\hline & & $\begin{array}{l}\text { Menyebutkan symbol } \\
\text { huruf konsonan pada } \\
\text { kata di media big book }\end{array}$ & & & & \\
\hline & & $\begin{array}{l}\text { Menyebutkan } \\
\text { kelompok gambar } \\
\text { yang memiliki simbol } \\
\text { huruf awal yang sama } \\
\text { di media big book }\end{array}$ & & & & \\
\hline & & $\begin{array}{l}\text { Menyebutkan } \\
\text { kelompok gambar } \\
\text { yang memiliki simbol } \\
\text { huruf akhir yang sama } \\
\text { di media big book }\end{array}$ & & & & \\
\hline & & $\begin{array}{l}\text { Menyebutkan } \\
\text { kelompok gambar } \\
\text { yang memiliki bentuk } \\
\text { huruf yang hampir } \\
\text { sama pada media big } \\
\text { book misalnya: b dan d }\end{array}$ & & & & \\
\hline & $\begin{array}{l}\text { Mengenal } \\
\text { bunyi huruf }\end{array}$ & $\begin{array}{l}\text { Menyebutkan bunyi } \\
\text { huruf awal dari benda- } \\
\text { benda yang ada di } \\
\text { sekitarnya yang sama } \\
\text { dengan bunyi huruf } \\
\text { awal di media big } \\
\text { book }\end{array}$ & & & & \\
\hline & & $\begin{array}{l}\text { Menyebutkan bunyi } \\
\text { huruf akhir dari } \\
\text { benda-benda yang ada } \\
\text { di sekitarnya yang } \\
\text { sama dengan bunyi } \\
\text { huruf akhir di media } \\
\text { big book }\end{array}$ & & & & \\
\hline
\end{tabular}




\begin{tabular}{|c|c|}
\hline & $\begin{array}{l}\text { Menyebutkan huruf } \\
\text { yang hampIr sama } \\
\text { bunyinya pada media } \\
\text { big book misalnya: } \mathrm{p} \\
\text { dan v }\end{array}$ \\
\hline \multirow[t]{7}{*}{$\begin{array}{l}\text { Asosiasi } \\
\text { bunyi dan } \\
\text { symbol huruf }\end{array}$} & $\begin{array}{l}\text { Menunjukkan huruf } \\
\text { yang disebutkan pada } \\
\text { media big book }\end{array}$ \\
\hline & $\begin{array}{l}\text { Menyebutkan huruf } \\
\text { yang ditunjukkan pada } \\
\text { media big book }\end{array}$ \\
\hline & $\begin{array}{l}\text { Menyebutkan huruf } \\
\text { yang hilang dari kata } \\
\text { di media big book }\end{array}$ \\
\hline & $\begin{array}{l}\text { Menyebutkan bunyi } \\
\text { gabungan dari dua huruf } \\
\text { yang terdiri dari } \\
\text { konsonan dan konsonan } \\
\text { pada media big book } \\
\text { misalnya: ng, ny }\end{array}$ \\
\hline & $\begin{array}{l}\text { Menyebutkan bunyi } \\
\text { gabungan dari dua } \\
\text { huruf yang terdiri dari } \\
\text { vocal dan vocal pada } \\
\text { media big book } \\
\text { misalnya: ai, au, ae, } \\
\text { ao, dan lain-lain }\end{array}$ \\
\hline & $\begin{array}{l}\text { Menyebutkan bunyi } \\
\text { gabungan dari dua } \\
\text { huruf yang terdiri dari } \\
\text { konsonan dan vocal } \\
\text { pada media big book }\end{array}$ \\
\hline & $\begin{array}{l}\text { Menyebutkan satu } \\
\text { persatu huruf yang } \\
\text { membentuk katapada } \\
\text { media big book }\end{array}$ \\
\hline
\end{tabular}

Teknik analisis data yang digunakan yaitu teknik analisis kuantitatif dan kualitatif. Data yang diperoleh selama penelitian dari lembar observasi dianalisis dengan menghitung rata-rata jawaban berdasarkan skoring yang diperoleh. Skor ideal untuk seluruh item sama dengan 4 kali jumlah item. Jadi, berdasarkan perolehan skor maka dihitung tingkat persentasenya menggunakan rumus:

$$
P=\frac{J S}{N} \times 100 \%
$$


Risnita \& Winda Oktaviana: Asesmen Kemampuan Mengenal Huruf Anak Usia Dini Melalui Media Bigbook

\section{Keterangan:}

$\mathrm{P} \quad=$ Angka persentase keaktifan

Js = Jumlah skor yang dicapai

$\mathrm{N}=$ Jumlah skor ideal keseluruhan

$\mathrm{P}=\frac{\text { Jumlah skor yang dicapai }}{\text { Jumlah skor ideal keseluruhan }} \times 100 \%$

$\mathrm{P}_{\text {maks }}=\frac{80}{80} \times 100 \%=100 \%$

$\mathrm{P}_{\min }=\frac{20}{80} \times 100 \%=25 \%$

Kriteria penilaian kemampuan mengenal huruf anak adalah sebagai berikut:

Tabel 2. Kriteria Penilaian Kemampuan Mengenal Huruf Anak

\begin{tabular}{ccc}
\hline Skor Perolehan & Persentase Skor & Kriteria Penilaian \\
\hline $61-80$ & $76 \%-100 \%$ & BSB \\
\hline $41-60$ & $51 \%-75 \%$ & BSH \\
\hline $21-40$ & $26 \%-50 \%$ & MB \\
\hline $0-20$ & $0 \%-25 \%$ & BB \\
\hline
\end{tabular}

Penelitian ini dikatakan berhasil apabila anak mengalami peningkatan perkembangan kemampuan mengenal huruf menggunakan media big book sebesar $\geq$ $76 \%$ atau dengan kriteria berkembang sangat baik.

\section{Pembahasan}

\section{Keadaan Peserta Didik TK Mutiara Al-Madani Kota Sungai Penuh}

Penelitian dilakukan di Taman Kanak-kanak Mutiara Almadani yang berlokasi di Jalan Yos Sudarso Nomor 28 Kota Sungai Penuh Provinsi Jambi.

Jumlah peserta didik Taman Kanak-kanak Mutiara Al-Madani Kota Sungai Penuh tahun pelajaran 2016/2017 adalah 200 orang yang terdiri dari 107 orang laki-laki dan 93 orang perempuan dan terbagi kedalam 10 kelompok belajar, yaitu 3 kelompok A dan 7 kelompok B. Adapun kelompok belajar yang menjadi sampel tindakan adalah kelompok B3 dengan jumlah anak sebanyak 20 orang anak.

\section{Asesmen Kemampuan Mengenal Huruf Anak}

Hasil penelitian menunjukkan adanya peningkatan kemampuan mengenal huruf anak pada setiap siklus. Perbandingan persentase kemampuan mengenal huruf anak pada Prasiklus, siklus I, siklus II dan siklus III dapat disajikan pada tabel di bawah ini: 
Tabel 3. Perbandingan Persentase Perkembangan Kemampuan Mengenal Huruf Anak Prasiklus, Siklus I, Siklus II, dan Siklus III

\begin{tabular}{clrccc}
\hline No & Nama Anak & Prasiklus & Siklus I & Siklus II & Siklus III \\
\hline 1 & AF & $50.00 \%$ & $91.67 \%$ & $100.00 \%$ & $100 \%$ \\
\hline 2 & AM & $50.00 \%$ & $66.67 \%$ & $75.00 \%$ & $91.67 \%$ \\
\hline 3 & AA & $50.00 \%$ & $83.33 \%$ & $91.67 \%$ & $100.00 \%$ \\
\hline 4 & AR & $33.33 \%$ & $50.00 \%$ & $75.00 \%$ & $91.67 \%$ \\
\hline 5 & DA & $41.67 \%$ & $50.00 \%$ & $66.67 \%$ & $91.67 \%$ \\
\hline 6 & DF & $50.00 \%$ & $58.33 \%$ & $66.67 \%$ & $91.67 \%$ \\
\hline 7 & EF & $50.00 \%$ & $100.00 \%$ & $100.00 \%$ & $100.00 \%$ \\
\hline 8 & HI & $50.00 \%$ & $50.00 \%$ & $75.00 \%$ & $83.33 \%$ \\
\hline 9 & HO & $50.00 \%$ & $50.00 \%$ & $66.67 \%$ & $91.67 \%$ \\
\hline 10 & KH & $33.33 \%$ & $50.00 \%$ & $66.67 \%$ & $91.67 \%$ \\
\hline 11 & LP & $50.00 \%$ & $83.33 \%$ & $100.00 \%$ & $100.00 \%$ \\
\hline 12 & ML & $50.00 \%$ & $58.33 \%$ & $75.00 \%$ & $91.67 \%$ \\
\hline 13 & MN & $33.33 \%$ & $58.33 \%$ & $66.67 \%$ & $75.00 \%$ \\
\hline 14 & MF & $50.00 \%$ & $50.00 \%$ & $66.67 \%$ & $83.33 \%$ \\
\hline 15 & MS & $50.00 \%$ & $66.67 \%$ & $75.00 \%$ & $91.67 \%$ \\
\hline 16 & RI & $33.33 \%$ & $50.00 \%$ & $66.67 \%$ & $75.00 \%$ \\
\hline 17 & R & $33.33 \%$ & $50.00 \%$ & $75.00 \%$ & $75.00 \%$ \\
\hline 18 & VZ & $50.00 \%$ & $50.00 \%$ & $75.00 \%$ & $83.33 \%$ \\
\hline 19 & ZL & $50.00 \%$ & $50.00 \%$ & $58.33 \%$ & $83.33 \%$ \\
\hline 20 & ZH & $50.00 \%$ & $50.00 \%$ & $58.33 \%$ & $75.00 \%$ \\
\hline & & & & \\
\hline
\end{tabular}

Persentase perbandingan kemampuan mengenal huruf anak pada prasiklus, siklus I, siklus II dan siklus III dapat dijelaskan pada diagram di bawah ini:

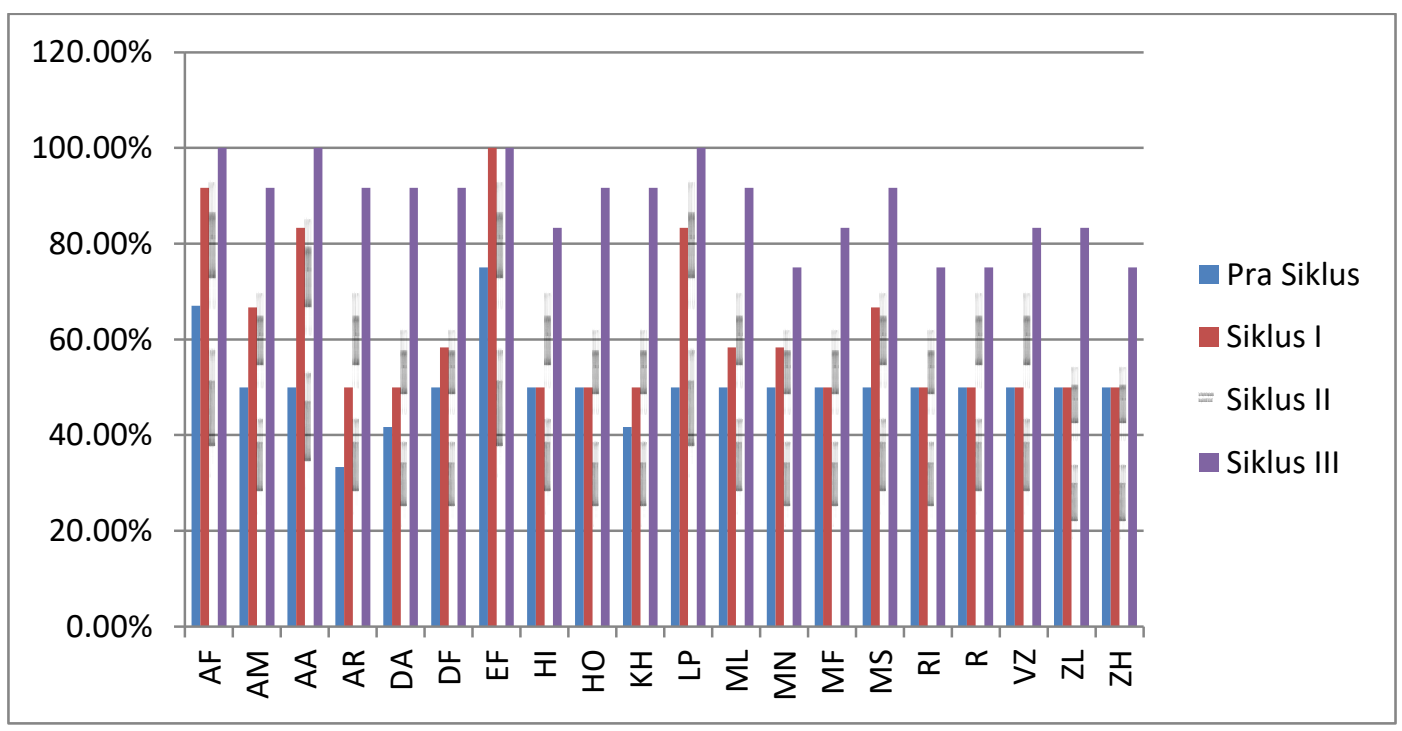

Diagram 1: Perbandingan Persentase Perkembangan Kemampuan Mengenal Huruf Anak pada Kondisi Prasiklus, Siklus I, Siklus II, dam Siklus III 
Risnita \& Winda Oktaviana: Asesmen Kemampuan Mengenal Huruf Anak Usia Dini Melalui Media Bigbook

Adapun peningkatan kemampuan mengenal huruf anak pada setiap indikator yaitu mengenal simbol huruf, mengenal bunyi huruf dan memahami asosiasi bunyi dan bentuk huruf dapat dilihat pada tabel di bawah ini:

Tabel 4. Peningkatan Kemampuan Mengenal Huruf Anak dari Prasiklus, Siklus I, Siklus II dan Siklus III

\begin{tabular}{clccccc} 
No & $\begin{array}{c}\text { Indikator Kemampuan } \\
\text { Mengenal Huruf }\end{array}$ & $\begin{array}{c}\text { Pra } \\
\text { siklus }\end{array}$ & $\begin{array}{c}\text { Siklus } \\
\text { I }\end{array}$ & $\begin{array}{c}\text { Siklus } \\
\text { II }\end{array}$ & $\begin{array}{c}\text { Siklus } \\
\text { III }\end{array}$ & $\begin{array}{c}\text { Peningkatan } \\
\text { Persentase }\end{array}$ \\
\hline 1 & Mengenal Simbol Huruf & $50 \%$ & $63,75 \%$ & $80 \%$ & $93,75 \%$ & $43,75 \%$ \\
\hline 2 & Mengenal Bunyi Huruf & $45 \%$ & $60 \%$ & $76,25 \%$ & $91,25 \%$ & $46,25 \%$ \\
\hline 3 & $\begin{array}{l}\text { Asosiasi Bunyi dan } \\
\text { simbol Huruf }\end{array}$ & $40 \%$ & $58,75 \%$ & $68,75 \%$ & $80 \%$ & $40 \%$ \\
\hline $\begin{array}{l}\text { Rata-rata pencapaian } \\
\text { kemampuan anak }\end{array}$ & $45 \%$ & $60,42 \%$ & $75 \%$ & $88,33 \%$ & $43,33 \%$ \\
\hline
\end{tabular}

Dari tabel di atas dapat dideskripsikan bahwa rata-rata pencapaian kemampuan mengenal huruf anak pada siklus III meningkat yaitu mencapai 88,33\% dengan persentase peningkatan $43,33 \%$. Hal ini berarti terlihat adanya perkembangan kemampuan mengenal huruf anak dalam mengenal simbol huruf, mengenal bunyi huruf dan memahami asosiasi bunyi dan bentuk huruf. Perkembangan tersebut telah mencapai kriteria keberhasilan yang di harapkan yaitu $\geq 76 \%$.

Hasil observasi Prasiklus, Siklus I, Siklus II, dan Siklus III menunjukkan bahwa media big book dapat mengembangkan kemampuan mengenal huruf pada anak Taman Kanak-kanak Mutiara Al-Madani Kota Sungai Penuh. Oleh karena itu peneliti menganggap hasil dari Siklus III sesuai dengan kriteria keberhasilan yang diharapkan.

Perbandingan kemampuan mengenal huruf anak pada kondisi awal Siklus I, Siklus II, dan Siklus III disajikan pada diagram di bawah ini:

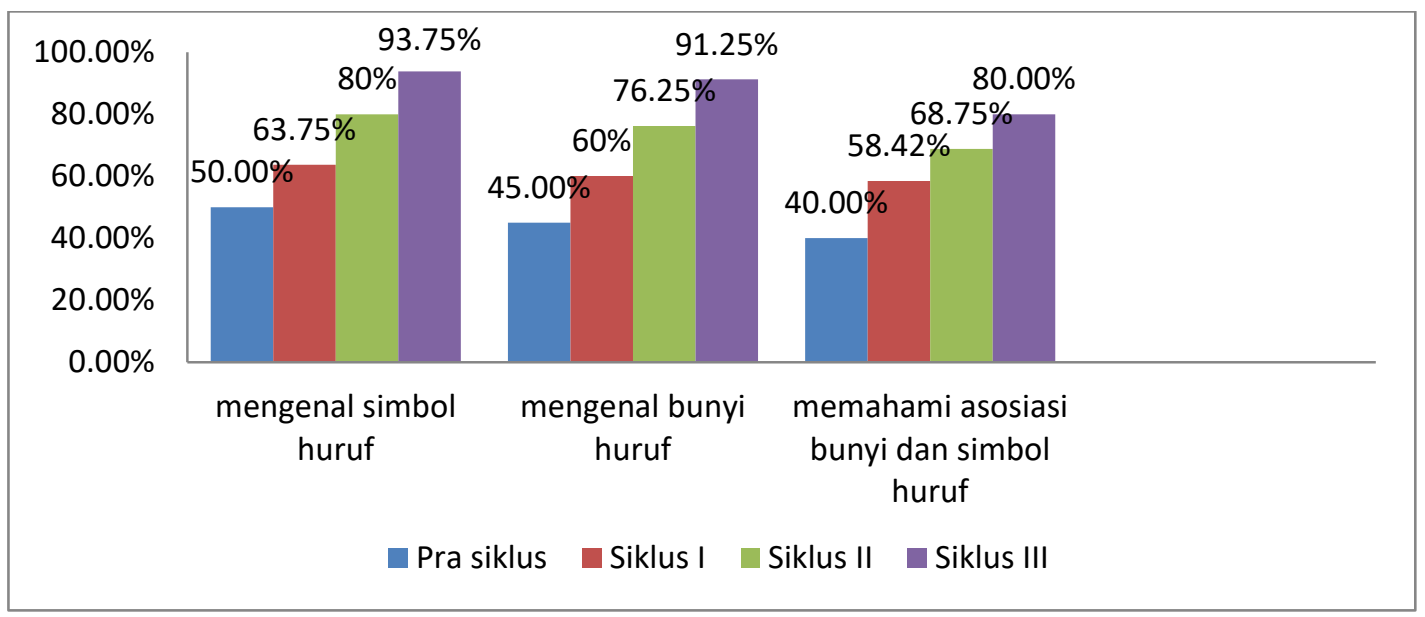

Diagram 2 : Peningkatan Kemampuan Mengenal Huruf Anak dari Prasiklus, Siklus I, Siklus II dan Siklus III 
Melalui penggunaan media big book, pengenalan huruf dapat dikenalkan dengan cara yang menyenangkan. Anak terlihat sangat antusias ketika dikenalkan huruf dengan menggunakan media big book. Pengenalan huruf dapat dilakukan dengan cara bermain akan meningkatkan partisipasi anak secara aktif dalam pembelajaran. Hal ini terlihat dari hasil prasiklus, siklus I, siklus II, dan siklus III mengalami peningkatan. Adapun skor yang diperoleh anak prasiklus adalah $45 \%$. Pada siklus I skor yang diperoleh anak adalah 60,83. Pada Siklus II skor yang diperoleh anak adalah 75\%. Pada siklus III skor yang diperoleh anak adalah $88,33 \%$

\section{Kesimpulan}

Berdasarkan hasil penelitian disimpulkan bahwa melalui penggunaan media big book dapat mengembangkan kemampuan mengenal huruf anak kelompok B3 Taman Kanak-kanak Mutiara Al-Madani Kota Sungai Penuh. Peningkatan perolehan skor yang didapatkan anak semakin meningkat pada setiap siklusnya yaitu dari prasiklus, siklus I, siklus II, dan siklus III. Peningkatan ini menunjukkan hasil yang baik. hasil ini menunjukkan melalui penggunaan media big book pada anak akan membuat anak tertarik pada kegiatan pembelajaran dan berpengaruh dalam mengembangkan kemampuan mengenal huruf pada anak.

\section{E. Daftar Pustaka}

Aisyah, Siti, et.al. Perkembangan dan Konsep Dasar Pengembangan Anak Usia Dini. Jakarta: Universitas Terbuka, 2010.

Aqib, Zainal. Penelitian Tindakan Kelas Bagi Pengembangan Profesi Guru. Bandung: Yrahma Widya, 2006.

Aulina, Choirun Nisak. "Pengaruh Permainan dan Penguasaan Kosakata terhadap Kemampuan Membaca Permulaan Anak Usia 5-6 Tahun.” Jurnal Pendidikan Anak Usia Dini, Vol. 6 No. 2 (2012).

Departemen Pendidikan Nasional. Undang-Undang Sistem Pendidikan Nasional. Jakarta: Departemen Pendidikan Nasional. 2003.

Dhieni, Nurbiana, et.al. Metode Pengembangan Bahasa. Jakarta: Universitas Terbuka, 2008.

Dyer, Laura. Meningkatkan Kemampuan Bicara Anak. Jakarta: Bhuana Ilmu Populer. 2009.

Hall, Usan Colville dan Barbara O'Connor. "Using Big books: A Standards-Based Instructional Approach For Foreign Language Teacher Candidates in a Prek-12 Program.” Foreign Language Annals, Vol. 39, No. 3 (2006). 
Risnita \& Winda Oktaviana: Asesmen Kemampuan Mengenal Huruf Anak Usia Dini Melalui Media Bigbook

Kementerian Pendidikan dan Kebudayaan. Peraturan Menteri Pendidikan dan Kebudayaan Republik Indonesia Nomor 137 Tahun 2014 tentang Standar Pendidikan Anak Usia Dini. Jakarta: Kementerian Pendidikan dan Kebudayaan. 2015.

Kustandi, Cecep. Media Pembelajaran Manual dan Digital. Bogor: Ghalia Indonesia. 2011.

Madyawati, Lilis. Strategi Pengembangan Bahasa pada Anak. Jakarta: Prenadamedia Group, 2016.

Mulyasa, E. Manajemen PAUD. Bandung: PT. Remaja Rosdakarya, 2012.

Musfiroh, Tadkiroatun. Bermain Sambil Belajar dan Mengasah Kecerdasan. Jakarta: Departemen Pembinaan Tenaga Kependidikan dan Ketenagaan Perguruan Tinggi, 2009.

Mutiah, Diana. Psikologi Bermain Anak Usia Dini. Jakarta: Kencana Prenada Media Group. 2012.

Ocbian, Magdalena M., et.al., "Big books'as Mother Tongue-Based Instructional Materials in Bicol for Grade One Pupils." Asia Pasific Journal of Multidisciplinary Research, Vol. 3 No. 4 (2015).

Patmonodewo, Soemiarti. Pendidikan Anak Prasekolah. Jakarta: Rieneka Cipta, 2008.

Qadratillah, Meity Taqdir, et.al. Kamus Bahasa Indonesia untuk Pelajar. Jakarta: Badan Pengembangan dan Pembinaan Bahasa, Kementerian Pendidikan dan kebudayaan, 2011.

Santrock, Jhon W. Education Psycology. Newyork: McGraw-Hill, 2006.

Seefeldt, Carold dan Barbara A. Wasik. Pendidikan Anak Usia Dini. Terjemahan Piur Nasar. Jakarta: PT. Indeks, 2008.

Sholehuddin, M., et.al. Pembaharuan Pendidikan TK. Jakarta: Universitas Terbuka. 2010.

Suyanto, Kasihani K.E. English for Young Learners. Jakarta: Bumi Aksara, 2008.

Wiyani, Novan Ardy dan Barnawy. Format PAUD. Jakarta:Ar-Ruzz Media, 2012.

Yufiarti dan Titi Chandrawari. Profesionalitas Guru PAUD. Jakarta: Universitas Terbuka, 2010

Yulsyofriend. Permainan Membaca dan Menulis Anak Usia Dini. Padang: Sukabina, 2009. 